\title{
The Gender Backlash in the Vote for Brexit
}

\author{
Jane Green $^{1}$ (D) $\cdot$ Rosalind Shorrocks $^{2}$ (D)
}

Accepted: 22 March 2021 / Published online: 3 April 2021

(c) Crown 2021

\begin{abstract}
Despite a relationship between gender and support for populist causes in crossnational research, including in the 2016 US Presidential election, the role of gender has been missing in analysis of support for Brexit, most likely because women and men showed no average aggregate-level differences in voting Leave or Remain. This misses an important explanation for Britain's vote to leave the European Union. We demonstrate how gender-based resentment motivated Leave votes in the EU referendum through perceptions of discrimination against men, among men. Using novel survey measures, we demonstrate (i) the distinct nature of perceptions of discrimination towards men in comparison with discrimination towards women; (ii) the sociological sources of perceptions that men are discriminated against; and (iii) the role of these perceptions in Brexit support. Our findings reveal that the Brexit referendum provided an opportunity to express broader social grievances than have, to date, been identified as relevant. The paper therefore offers a novel contribution to understanding the cultural backlash behind Britain's vote to leave the EU, and by so doing, insight into the potential for gender-based backlash effects in elections where gender isn't significantly primed, unlike the 2016 US presidential election where gender was a major political focus.
\end{abstract}

Keywords Gender · Discrimination · Perceptions · Brexit · Cultural backlash

\section{Introduction}

Concerns over a gender 'backlash' have been growing in recent years. From Donald Trump in the US to Jair Bolsonaro in Brazil, voters are electing candidates who have taken explicit stands against prevalent norms of gender equality. In the US, voters who believed that women had unfair advantages and that men were discriminated against were particularly likely to vote for Trump in 2016 (Cassino, 2016; Goldman,

Jane Green

jane.green@nuffield.ox.ac.uk

$1 \quad$ Nuffield College, New Road, Oxford OX1 1NF, UK

2 Department of Politics, University of Manchester, Oxford Road, Manchester M13 9PL, UK 
2018). Despite this, there has been no examination of the effects of such attitudes elsewhere, although cultural backlash theories argue that certain groups-specifically older, white, economically disadvantaged men - are reacting with anger and resentment against long-term economic, social, and cultural change that they perceive has left them behind, challenged their social and economic status, and left them nostalgic for their previously higher status (Gest, 2016; Gidron \& Hall, 2017; Norris \& Inglehart, 2019). Increasing gender equality and economic competition with women represent some of the largest changes to society and should lead us to expect that any cultural backlash contains a gendered dimension.

In this paper, we examine the gender dimension of the backlash in the British case, and specifically in the referendum on the UK's EU membership in June 2016 (Brexit). Britain is an especially useful context since it has been directly compared to the US in terms of experiencing a backlash against economic and cultural change, expressed in the vote to leave the EU as a desire for sweeping changes not directly associated with EU membership (e.g. Goodwin \& Heath, 2016; Gest et al., 2018). However, gender was not overtly politicised as part of the EU referendum campaign, and the binary-choice referendum offered options which did not clearly map onto existing party ideologies and programmes. The EU referendum thus presents a hard but important test of the role of a gender backlash in political behavior in a comparative context.

We show how gender discrimination attitudes shaped EU referendum vote choice. Leveraging novel measures in the British Election Study Internet Panel (Fieldhouse et al., 2015) for c.17,000 respondents, we show that perceiving discrimination against men increases voters' likelihood for voting Leave, especially amongst men, and that the substantive size of the effect is comparable to that for attitudes about racial discrimination. These findings are robust when we control for past EU referendum vote choice. We assess the extent to which respondents perceive discrimination against men and women as a measure of gender-based grievance (Cassino, 2016; Kehn \& Ruthig, 2013), and provide new insights into the nature of different discrimination perceptions by gender, in particular how these do not actually vary by income, social class, or by education level. Examining the source of these perceptions, we find that men are more likely to perceive discrimination against men than women are. This is true for men of all ages, but is particular the case for young men out of work. This grievance-basis of political attitudes is more nuanced (by age and working status) than existing accounts which focus on levels of income and education. We argue that perceiving discrimination against men is a gendered element of the broader cultural backlash and nostalgia, associated with voting Leave because of how the Leave campaign presented itself as a broad rejection of the status quo, offering an outlet for resentments and dissatisfaction with changes in society, as well as being specifically about sovereignty and EU membership.

We conclude that we should take gender far more seriously in theoretical and empirical work on the cultural backlash thesis, supporting other work that posits this effect (Norris \& Inglehart, 2019). While the experiences of men have been highlighted by several influential works, we need a deeper understanding of why men demonstrate greater propensity to vote against the status quo, in support of populism, and on the basis of perceived discrimination against men. Changes with respect to 
gender equality have been as drastic as changes to the economy or racial diversity in established democratic societies, but the possible consequences of this have received much less attention. Our findings show that the gender backlash is widely relevant for political behaviour, even in a context where gender was not particularly salient, providing an important comparative example where this gender-backlash effect is in play. Overlooking gender discrimination effects overlooks an important phenomenon shaping recent political outcomes.

\section{Previous Literature and Theoretical Expectations}

\section{Backlash and Gender Resentment}

Resentments and grievances related to economic, social, and cultural change have become a prominent part of explanations for why some voters support populist and radical right parties, including Donald Trump in the United States, and Brexit in the United Kingdom (e.g. Gest, 2016; Gest et al., 2018; Gidron \& Hall, 2017; Norris \& Inglehart, 2019). Certain segments of the populace-especially white, older, working class men-feel marginalised and resentful as a result of social, economic, and cultural change that has 'left them behind'. They form part of a backlash against these changes by voting for radical or populist options at the ballot box. While it is argued that the backlash is largely concentrated amongst (some) men, and indeed there is a consistently noted gender gap in support for populist radical right parties, the extent to which grievances and resentments are based on gender is rarely explicitly explored, especially outside of the US. In US research, sexism and perceptions of gender favouritism were clearly associated with voting for Trump in 2016 (e.g. Bock et al., 2017; Goldman, 2018), but the specifics of that election (Donald Trump's record, behavior and tone, the salience of the gender of the candidates, and the longer-term importance of a gender gap in US elections) make the generalisability of gender-based resentment effects on electoral behaviour challenging.

The 'backlash' argument is rooted in the marginalisation of certain social groups related to economic precarity, declining social status, and the diminishing of traditional cultural values; three developments which are overlapping and intertwined. Economic precarity has grown amongst the white working class as a result of declining job security, rising socioeconomic inequality and declining social mobility, and the decline of traditional, 'respectable' working class jobs in the manufacturing industry (Gidron \& Hall, 2017). As a result, the white working class have been described as holding a sense of 'nostalgic deprivation' (Gest, 2016; Gest et al., 2018), based on the idea that they used to have greater status but their previously high status is now held by other groups. They blame elites for their changing circumstances and so react against the status quo (Gest, 2016; Steenbergen \& Siczek, 2017). This resentment is fuelled by political and media discourse, directing a sense of status loss into resentments towards elites, immigrants, and other minorities (Bonikowski, 2017).

Crucially, developments such as those described above are seen as particularly affecting men in white working-class communities who used to hold the secure, 
stable, manual jobs which have been declining over past decades. Gidron and Hall (2017) find that it is particularly men without a college education whose subjective social status has declined over time in post-industrial societies, and who are more anti-elitist, anti-immigrant, and anti-globalisation. Gidron and Hall explain this loss of male status by arguing that working-class men have been particularly negatively affected by technological change, low pay, and low job security, and have been unable to take advantage of changes to the economy which mean higher rewards accrue to those at higher levels of education. Women, on the other hand, have experienced a relative status increase as they have entered the workforce in growing numbers. ${ }^{1}$ As a result, Gidron and Hall (2017) find that the gap in subjective social status between men and women without a college education has declined over time: women perceived a lower status in the 1980s but as men's subjective social status declined, the gender gap became non-existent by 2010 . This gender difference in the experience of economic change has also been linked to the gender vote gap in support for radical right parties. Women are consistently less likely to vote for radical right parties than men, although the size of the gap varies across countries (Givens, 2004; Spierings \& Zaslove, 2015). This has been partly explained by men's greater representation in blue-collar occupations that are especially vulnerable to low pay and job insecurity as a result of globalisation (Givens, 2004; Immerzeel et al., 2015). Although women's position in the workforce is also often precarious in comparison to men's - through lower on average pay and the greater propensity to part-time work-this is not linked to globalisation and the decline of manufacturing in the same way as men's precarity. It is also important to note that the male status loss argument relies on a comparison between working class men's perceived relative social status in the past and present, rather than a direct comparison to women today.

Gidron and Hall (2017) test the effects of subjective social status decline on support for populist parties, immigration attitudes, and anti-elitism, but they do not examine whether men-whose social status has declined-feel resentful on the basis of their gender. They do argue that cultural frameworks have increasingly emphasised and promoted gender equality, reinforcing the negative effects of economic change that working-class men have experienced. This suggests that the effects of economic precarity and declining social status are compounded by cultural change with respect to gender equality and the decline of traditional values. Others have similarly argued that the salience of the divide between 'traditionalists' and those who are accepting and tolerant of ethnic diversity and gender equality has risen, with the traditionalists feeling like 'strangers in their own land' (Norris \& Inglehart, 2019, p. 123). Norris and Inglehart emphasise that it is older white men and nongraduates who are most likely to be 'traditionalists', because they feel marginalised; both culturally and economically. Similar cultural divides have been identified in Britain, where people in 'cosmopolitan' areas are more pro-immigration, pro-EU, and supportive of gender and racial equality, whilst people in towns and rural areas

\footnotetext{
1 For example, in 1971 the UK gap between the proportion of men and women in work was 39.3 percentage points, and in 2019 it was 8.2 points. See Office of National Statistics data: http://ow.ly/hzuS3 0p8ryw.
} 
are more anti-immigration, anti-EU, and nostalgic for the past (Jennings \& Stoker, 2016, 2017). This 'bifurcation of British politics' has become increasingly important, both in the lead up to the 2016 EU referendum and also afterwards.

In summary, the literature on backlash and grievance politics emphasises that economic changes such as globalisation and the decline of manufacturing have had particular negative consequences for working class men, that (some) men have perceived a greater status loss and hold traditional values as a result of sweeping economic, social, and cultural change, and also that gender-traditionalism is a component of these sources of political resentment. At the same time, economic shifts such as rising female labour force participation, and cultural shifts such as rising political, institutional, and public support for gender equality, have fundamentally re-shaped society, even if full gender equality has not been reached. This strongly suggests that gender-based resentment-and specifically male resentment-is part of the backlash. However, the extent to which gender-based resentment is held amongst the 'left behind', or the extent to which it can influence political choices, has not been empirically tested.

We focus in this paper on the concept and measure of gender discrimination, specifically on male resentment and grievance. A gender backlash can be measured through perceptions of discrimination, specifically through measuring perceptions of discrimination against men, and/or discrimination in favour of women. Such a measure is different to, for example, attitudes towards traditional gender roles or hostility towards women ('hostile sexism,' Glick \& Fiske, 1996, 2011)), because it explicitly focuses on attitudes about men's position in society and enables us to analyse the extent to which men feel discriminated against as men.

\section{Sources of Perceptions of Discrimination Against Men}

Research into perceptions of gender discrimination in the US suggests that men are more likely than women to perceive a bias against men (and women are more likely than men to perceive bias against women) (Kehn \& Ruthig, 2013). Men also see bias against men as increasing over time, whilst women do not, and both men and women see bias against women as decreasing over time. That is to say, men see a growing divide between men and women's status, but the same perception of a divide is not increasing among women. These findings are explained by the argument that men, as the traditionally dominant group, perceive gains in the status of women occurring at the expense of men, i.e., they see gender bias as zero-sum. Women, on the other hand, do not view women's progress in society as happening at the expense of men. This is, in turn, consistent with the finding that men have higher social dominance orientations, and thus have preferences to maintain the social hierarchies within which they are dominant (Pratto et al., 1994). Women do not have this preference as a result of their lower status in the hierarchy. This is similar to racial bias findings in the US, where white males see increases in the status of blacks occurring at the expense of the traditionally dominant group, whites, whilst women and black respondents do not see the same zero-sum relationship between declining anti-Black bias and rising anti-white bias (Norton \& Sommers, 2011). 
The cultural backlash literature (discussed above) suggests that it is not all men who should be particularly resentful on the grounds of gender; it is specifically economically, socially, and culturally marginalised men who are most likely to hold these views. Men in economically precarious positions should be most likely to perceive discrimination against men and discrimination in favour of womenas they have experienced the most status decline, whilst women's social status has risen (Gidron \& Hall, 2017; Norris \& Inglehart, 2019). This should especially be the case if men see traditional manufacturing and industrial employment as 'male' jobs, which seems likely to be the case given occupational sex-segregation, especially in manual occupations (Roos \& Stevens, 2018). Consistent with this expectation, working class men with lower levels of education are in general more likely to vote for populist radical right parties and hold authoritarian and populist views (Gest et al., 2018; Gidron \& Hall, 2017; Givens, 2004; Norris \& Inglehart, 2019), but the presence of resentment-and especially genderbased resentment-amongst this group has not been measured. We thus draw on cultural backlash theories and test directly the extent to which low-income, loweducation and working-class men are especially likely to perceive discrimination against men.

We also have some doubts about the extent to which economic position should matter for gender-based resentment, and specifically for the extent to which men perceive discrimination against men, despite this being the expectation generated from the existing literature. This is because it is also possible-likely even-that men with higher socioeconomic positions, who are not necessarily economically marginalised, are just as likely to perceive discrimination against men in terms of gender equality, and relative to women. In recent years, whilst women's employment rates have increased fairly slowly, there has nonetheless been an increase in women entering into especially professional and managerial professions (Fitzenberger \& Wunderlich, 2004; Kay, 1996). The occupations which have experienced an increase in women's employment relative to men have tended to be those that require higher levels of education, and women have made inroads into even such occupations which have typically been, and often remain, 'masculinised' e.g. in the 'hard' sciences. At the same time, skilled or semi-skilled 'masculine' occupations have seen an increase in masculinisation and continuing occupational sex-segregation (Roos \& Stevens, 2018). Therefore, even with persistent occupational sex-segregation, men in professional and managerial occupations are more likely to experience more women in the labour force than men in the lower skilled jobs that remain masculinised, yet more precarious. Importantly, women in such professional work environments have been found to indeed experience a backlash. Women experience bias in hiring processes and are perceived as less capable and effective than men (Eagly \& Karau, 2002; Phelan \& Rudman, 2010). This suggests that if women are perceived as less effective but are still hired and promoted, discrimination is thought to take place in favour of women and against men. The backlash faced by women in employment is also especially strong in industries deemed 'incongruent' with femininity (Garcia-Retamero \& López-Zafra, 2006). This indicates that it is especially in traditionally masculine professions which still have a larger proportion of male employees to female employees, that women should be perceived negatively. 
The arguments above suggest that men across all class levels would have reason to perceive men to be discriminated against: those at lower socioeconomic positions because of the loss of status for traditional, working-class, 'men's' jobs, and those at higher socioeconomic positions because of their more direct experience of increasing competition with women entering the labour market and consequent backlash against this development. Thus, despite the implicit expectation in the literature about lower income, lower-educated men being the males who should be most resentful, a competing expectation is that socioeconomic position does not matter for gender-based resentment. Our first set of hypotheses thus specify two competing expectations:

H1A Perceptions of discrimination against men will be higher amongst men with low incomes and men with lower levels of education.

H1B Perceptions of discrimination against men will be higher amongst men of all income and education levels, relative to women.

Older generations are especially likely to hold traditional and authoritarian views compared to younger generations (Norris \& Inglehart, 2019). Moreover, women's position in society has changed quickly, especially since the 1970s: the women's employment rate has grown from below $60 \%$ in 1975 to nearing $80 \%$ today, with much of the increase driven by increases in women's fulltime employment, which grew from $30 \%$ in 1985 to nearly $45 \%$ today (Roantree $\&$ Vira, 2018). These increases have largely been driven by married women entering the workforce at much higher levels than in the past. Thus, whilst economic activity is the norm for younger generations of women, older generations will recall when the traditional male-breadwinner model was dominant. This is reflected in clear generational differences about gender roles, with older generations being more supportive of traditional configurations for work and family life (Berridge et al., 2009; Scott, 2008). Older men in particular are the most likely to perceive anti-male bias, and also, as discussed, see this as zero-sum (Kehn \& Ruthig, 2013). We therefore expect that older generations, especially older men, will be more likely to perceive discrimination against men, as their expectations and early life experiences have been challenged by changes in the workforce and wider social change.

An extension of this argument is that we should specifically expect older men in the workforce to be the most likely group to perceive discrimination against men and in favour of women. The growth of women's economic activity in the workforce, as well as their rising education rates, has been a key change to social life in the UK (Scott, 2008). For younger employed men, women in the workforce has always been a consistent feature of their work life experience. However, older men in the workforce will remember a time when men were much more dominant in the workplace, and have witnessed the growing entry of women. It is not the case that women have just increased their presence in female-dominated workplaces; as described above, they have also entered into higher skilled and 
professional occupations where they increasingly work alongside men and compete for the same jobs (Fitzenberger \& Wunderlich, 2004; Kay, 1996). It is thus the older men in the workforce who can both remember a more male-dominated environment and who have experienced changes in female employment levels, who we expect to perceive the most discrimination against men. This expectation is quite different to that produced by literature emphasising economic and social marginalisation. Instead, our argument suggests that gender-based resentment should be more prevalent amongst those whose current experience is most at odds with their past experience and who therefore feel marginalised and more economically precarious as a result-i.e., those who are in workplaces where women are gaining ground, but were socialised into their workplace life at a time when men were much more dominant and women were excluded. Whilst older men outside the workplace may have more traditional views on gender roles, we expect them to have lower levels of gender resentment than those in the workforce because they are not directly experiencing the rise in the status of women in the same way. We specify our second and third hypotheses as follows:

H2 Perceptions of discrimination against men will be higher amongst older men.

H3 Perceptions of discrimination against men will be higher amongst older employed men.

\section{Gender Resentment and Support for Brexit}

The vote to leave the EU was for some voters a ballot expressing dissatisfaction with the status quo (Steenbergen \& Siczek, 2017) and in particular an expression of "intense angst about rapid social, economic, and cultural change" (Goodwin \& Heath, 2016, p. 331; see also Norris \& Inglehart, 2019). Leave voters were concerned about the decline in service provision and financial support during austerity (Becker et al., 2017; Fetzer, 2019), the consequences of increased globalisation (Colantone \& Stanig, 2018), increasing experiences of low-paid and precarious employment (Hobolt, 2016), and the social, economic, and cultural consequences of immigration (Clarke et al., 2017; Goodwin \& Milazzo, 2017; Iakhnis et al., 2018). The Leave vote was not, therefore, just a policy-based rejection of European membership per se. Voting Leave was a broad rejection of the status quo, motivated by concerns and resentments about a sweeping array of social, cultural and economic change.

This backlash in the EU referendum rested on nostalgia for a previous, more desirable past. Nostalgia in various forms has been linked to voting for populist radical right parties in Europe (Steenvoorden \& Harteveld, 2018) and for UKIP and Donald Trump (Gest et al., 2018). Leave voters were substantially more likely to think that things were better in the past than were Remain voters (Swales, 2016), suggesting that the campaign to Leave successfully mobilised those who wanted to reverse widespread societal change. Richards et al. (2020) argue that we need to examine the specific content of nostalgia in the Leave vote, since existing accounts do not always specify exactly what 
Leave voters were nostalgic for. They show that Leave voters are 'traditional nostalgics', who think that ethnic diversity, same-sex relationships, and women entering the workforce are aspects of modern life that have made life worse.

Following these findings, we argue that perceptions of gender discrimination, measuring the gender dimension of the 'backlash', is a form of resentment about change and nostalgia for the past, and as such should be associated with voting Leave, alongside other predictors. In further support of this perspective, Kehn and Ruthig (2013) find that perceptions of anti-male bias have increased over time amongst (older) men, suggesting they should be nostalgic for a time when men's status was more dominant. This could then have contributed to their decision to vote to Leave, which was presented by the campaign as a nostalgic enterprise, taking Britain 'back' to a better past. Others have similarly noted that Brexit voting was partly driven by a perception of over-time relative gains amongst out-groups (Green et al., 2021), a logic which could also apply to gender. It should also be noted that although gender was not explicitly visible within either the Remain or the Leave campaign (Guerrina \& Murphy, 2016), the UK Independence Party (UKIP) and especially Nigel Farage (the leader of UKIP and a prominent campaigner for Brexit) portrayed a particularly 'masculine' image, with Nigel Farage adopting a 'blokeish' and 'working man's' persona, and making a series of derogatory comments about working women in particular (Daddow \& Hertner, 2019). Therefore, insofar as men perceiving discrimination and disadvantage by their gender were seeking representation in the UK's political debate, the foremost champion of leaving the European Union provided some of that representation. At the same time, the EU itself was associated with gender equality guarantees in the minds of some voters (BromleyDavenport et al., 2018).

We thus expect the Leave vote to be associated with gender-based resentment, specifically the perception that men are discriminated against. This demonstrates the depth and complexity of the backlash and nostalgia elements of the Brexit vote, going beyond economic decline and anti-immigration sentiment. We also therefore expect that perceiving discrimination against men should matter particularly for the Brexit vote of men. Whilst women might perceive discrimination against men, we should expect such gender-based resentment to matter more for men because they see themselves as the group who are disadvantaged by this discrimination. This discussion leads us to specify the following hypotheses:

H4 Leave voting is more likely if people perceive discrimination against men.

H5 Leave voting is more likely amongst men who perceive discrimination against men.

\section{Data and Methods}

We designed new survey questions to measure people's perceptions of discrimination for and against men, and for and against women, and we fielded these items alongside equivalent measures of discrimination for and against white British 
people, and ethnic minorities. This allows us to (a) examine whether discrimination for or against men corresponds to discrimination against or for women (are these attitudes symmetrical, that is, zero-sum, and if so, for whom); (b) examine the direction of perceptions of discrimination; whether respondents felt that there was discrimination against men, or in favour of women; and (c) benchmark perceptions of any gender-based discrimination against the effects of perceived racial discrimination, and control for those other perceptions in our models. The question stem was worded: "How much discrimination do you think there is in Britain today for or against each of the following groups?" with responses for 'men', 'women', 'black and Asian people', and 'White British people', where $0=\mathrm{a}$ lot of discrimination in favour and $10=\mathrm{a}$ lot of discrimination against. Don't know responses were removed from the analysis.

The questions were answered in the November 2016 wave (10) of the British Election Study Internet Panel (BESIP) by approximately 24,000 respondents. Our analysis is limited to a subset of c.17,000 of these respondents once we omit those who have missing values on the relevant control variables. The BESIP sample is weighted to be representative of the British population, and has the advantages of a large sample size as well as a range of control variables and questions about support for Leave in a hypothetical future referendum (wave 10 was fielded shortly after the 2016 EU referendum), as well as preferences over EU integration, which we use in robustness checks. As it is a panel, we are also able to control for respondents' prior support for leaving the EU (wave 9, the post EU referendum wave) in order to address possible endogeneity between EU referendum vote and our discrimination perception measures.

Our first dependent variable in the analysis is scores on the discrimination measures, focusing on perceptions of discrimination for or against men. Our subsequent dependent variable is vote intention: "If there was another referendum on EU membership, how do you think you would vote?", with responses Leave the EU (1) and Remain in the EU (0). Our explanatory variables across both sets of models (age, gender, education level, household income, social class identification, ${ }^{2}$ marital status, work status) are summarised in Table A1 in the Online Appendix along with controls (immigration attitudes, liberal-authoritarian values, left-right values, strength of British identity). We compare analyses-where useful—with perceptions of discrimination for or against women, white British people and black and Asian people. We report results with and without controls for liberal-authoritarian values (and left-right values) where we analyse the interaction effects with education level or age, since these demographics are strongly associated with authoritarianism, or social conservatism (Grasso et al., 2019; Surridge, 2016; Tilley, 2005).

\footnotetext{
2 At the time of writing, social class classification based on coded occupation status is not available. We therefore use subjective social class in a set of robustness checks on the results using household income.
} 

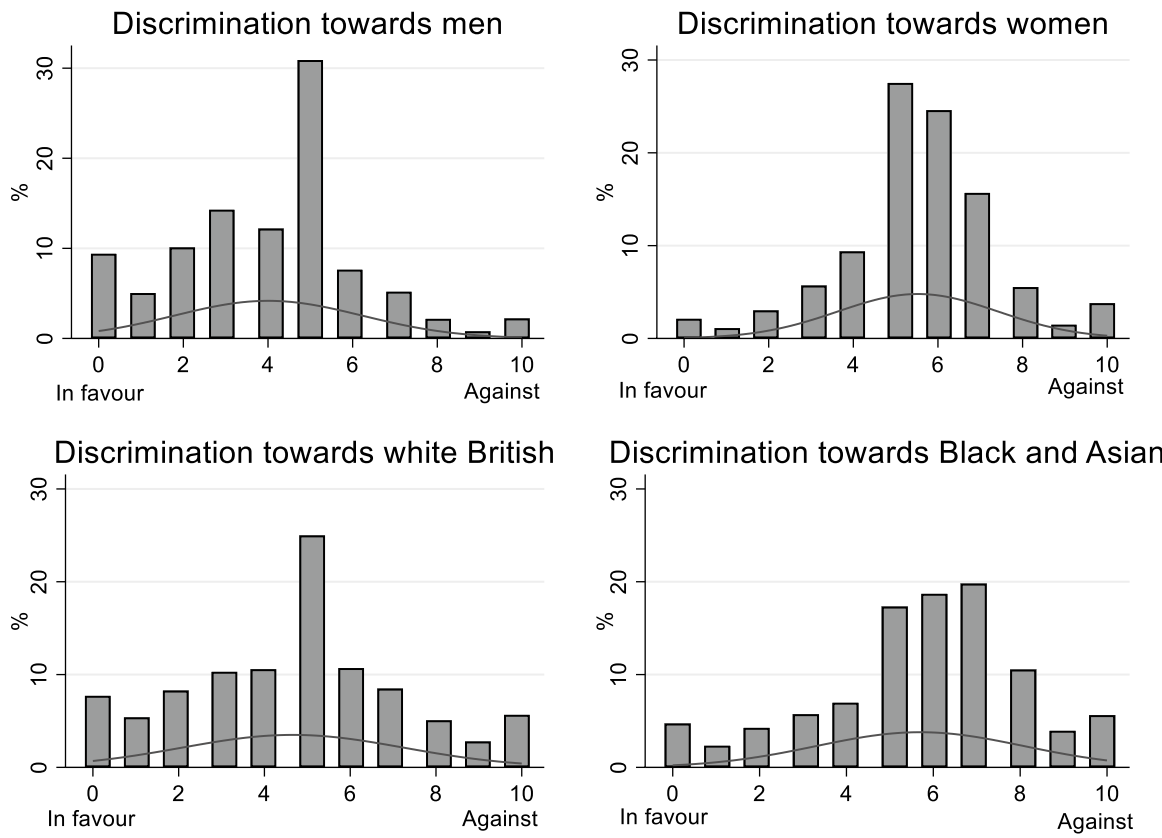

Fig. 1 Distributions of discrimination perceptions, British Election Study, November 2016. (Note 0=a lot of discrimination in favour, $10=\mathrm{a}$ lot of discrimination against)

\section{Results}

\section{Examining Discrimination Attitudes}

Figure 1 shows the distribution of responses across the four measures. Overall, a minority (19.2\%) of respondents perceive high levels of discrimination against men (scores of 6 and above). Higher proportions perceive discrimination against women (49.3\%), black and Asian people (57.6\%), and white British people (33.5\%). Furthermore, higher proportions perceive discrimination in favour of men than they do against men. Interestingly, the scales are not symmetrical between perceptions of discrimination against women and for men, or against ethnic minorities and for white British. Perceptions are not zero sum on average and across the population as a whole. ${ }^{3}$

\footnotetext{
${ }^{3}$ Don't know responses are relatively high for these variables: $17 \%$ for discrimination against men; $16 \%$ for discrimination against women; $16 \%$ for discrimination against Black and Asian people; and 17\% for discrimination against white people. It is notable, however, that the questions about discrimination against men and white people elicit similar levels of don't know response as the questions about discrimination against women and Black and Asian people. Women are also more likely to say they don't know than men: between $12-14 \%$ of men said they didn't know, compared to $18-21 \%$ of women. It should therefore be noted that whilst perceptions of discrimination are quite strongly held by some sections of the population, and are related to their political behaviour (as we demonstrate below), there is a subset of the population for whom these attitudes are not particularly meaningful.
} 
Table 1 Correlations in perceptions of discrimination

\begin{tabular}{lrccc}
\hline & \multicolumn{1}{l}{ Men } & Women & White British & Black and Asian \\
\hline Men & 1.0000 & & & \\
Women & -0.2575 & 1.00 & & \\
White British & 0.4880 & -0.1245 & 1.00 & 1.00 \\
Black and Asian & 0.2551 & 0.3844 & -0.4528 & \\
\hline
\end{tabular}

All data are weighted by wt_new_W10, N=23,999

Table 2 Correlations in perceptions of discrimination by gender

\begin{tabular}{|c|c|c|c|c|}
\hline & Men & Women & White British & Black and Asian \\
\hline \multicolumn{5}{|l|}{ Sample: women } \\
\hline Men & 1.0000 & & & \\
\hline Women & -0.1865 & 1.00 & & \\
\hline White British & 0.3966 & -0.0547 & 1.00 & \\
\hline Black and Asian & -0.1653 & 0.3127 & -0.4189 & 1.00 \\
\hline \multicolumn{5}{|l|}{ Sample: men } \\
\hline Men & 1.0000 & & & \\
\hline Women & -0.2380 & 1.00 & & \\
\hline White British & 0.5705 & -0.1596 & 1.00 & \\
\hline Black and Asian & -0.3053 & 0.4292 & -0.4749 & 1.00 \\
\hline
\end{tabular}

All data are weighted by wt_new_W10

This lack of symmetry can be seen more clearly with correlations between the measures, in Table 1. None of these correlations exceed 0.5 , and the correlation between perceptions of discrimination towards men and women is only -0.26 . This may be to do with discrimination itself, which may lead someone who is discriminated against to recognise the discrimination on their own group, but not to see a dominant group as being the beneficiary. The correlations support the measurement of these attitudes separately. ${ }^{4}$

We also compare the correlations between these perceptions by gender, in Table 2, and find differences in the strength of relationship in discrimination perceptions between men and women. The correlation between perceiving discrimination towards white British people and discrimination towards men is higher for men than for women, implying that men perceive 'white British people' as 'white British men' to a greater extent. Correlations are higher for men for all comparison

\footnotetext{
4 This is in contrast to a question fielded, historically, in the British Election Study post-election inperson surveys (which we use in robustness checks in this paper): "Please say whether you think these things have gone too far or have not gone far enough in Britain: Attempts to give equal opportunities to women" (responses $1=$ not gone nearly far enough, and 5=gone much too far). We discuss in the robustness checks section how these questions also show important and comparable effects, but the discrimination questions provide unique information on mechanisms, explanation and conditional relationships.
} 
groups, ${ }^{5}$ but neither gender relates white British people to their perceptions about women. There is only a weak correlation among men for the relationship between perceptions of discrimination towards women and men, which is weaker still among women, whereas men and women are similarly likely to evaluate discrimination towards white British people as negatively correlated with discrimination towards ethnic minorities (though never correlating more strongly than - 0.47).

We also look at the descriptive relationships between perceptions of discrimination and our political outcome of interest; supporting Leave in the Brexit referendum, shown in Fig. 2a and b. A higher proportion of Leave voting men-36.9\%report perceiving male discrimination. For Leave supporting women, the equivalent figure is much lower, at $13.2 \%$. Note that Leave voting respondents are much more likely to choose the mid-point than Remain voting respondents, suggesting that they are either more ambivalent about whether there is discrimination in an active or overt sense, or more reluctant to state that there is discrimination in favour of men (which women are much more likely to report) or strongly against. These distributions underline the value of modelling variance in attitudes across the whole distribution of responses, since we are interested in the explanatory power of these attitudes; their revealed behavioural importance across the $0-10$ scale.

The descriptive data give us a sense of the size of possible substantive effects of perceptions of gender discrimination. To set this in context, $51.6 \%$ of Leave voters perceive discrimination $(\geq 6)$ against white British people, and $36.9 \%$ perceive discrimination in favour of ethnic minorities. Perceptions of discrimination against men among male Leave voters $(36.9 \% \%)$ are close in range but not as high as levels of perceived discrimination against white British people. As these two are correlated for men, we control for the other discrimination perceptions when modelling the relationship between perceptions of male discrimination and EU referendum vote.

\section{Explaining Perceptions of Discrimination Against Men}

Table 3 reports the results of our OLS models of male discrimination. To recap, the literature pointed to greater gender-based resentments and grievances among low income, low education males (H1a). However, our expectations concerning increasing competition between men and women across different income and education levels also pointed us to expect higher perceptions of discrimination among men across all education and income levels (H1b). Table 3 presents results from OLS models, where model 1 is an additive model, model 2 adds an interaction between gender and age, model 3 adds an interaction between gender and education, and model 4 adds an interaction between gender and income. ${ }^{6}$

\footnotetext{
5 The correlations for men are statistically significantly stronger than they are for women in all cases, as tested by regression models with dependent variable of perceptions, and independent variable of other perceptions interacted with gender.

${ }^{6}$ Figure A1 (e) in the Online Appendix presents the results with subjective social class, which are consistent with those found for income in Table 3.
} 
\% Discrimination towards men by EU referendum vote: Men

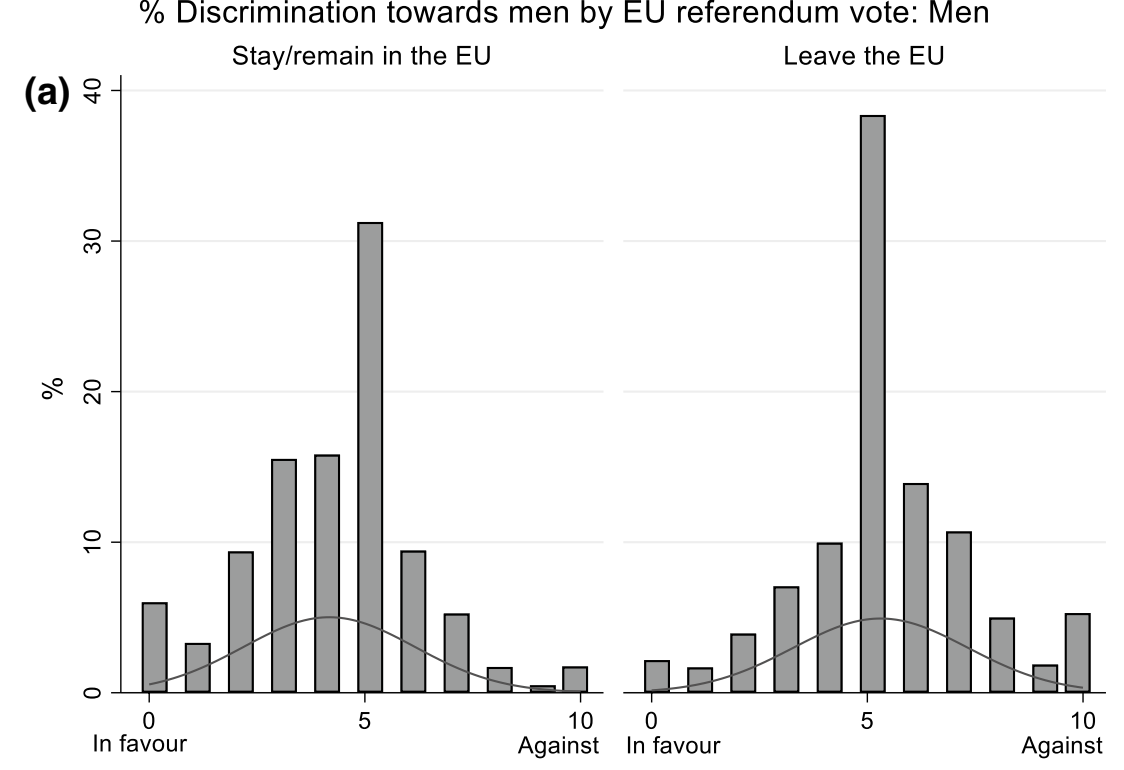

\% Discrimination towards men by EU referendum vote: Women

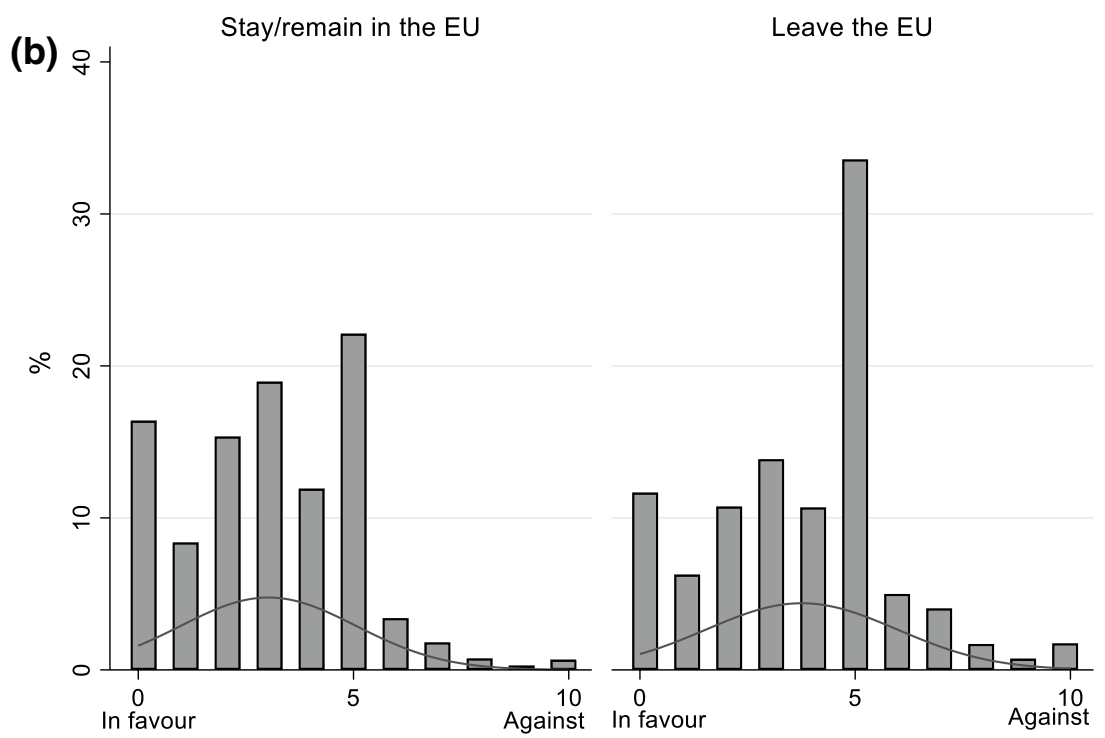

Fig. 2 a Perceptions of male discrimination by EU referendum vote (among men). b Perceptions of male discrimination by EU referendum vote (among women)

Model 1 shows that men are significantly more likely than women to perceive discrimination against men, even when socioeconomic characteristics are included in the model. The findings for models 3 and 4 show that this is the case across 
Table 3 OLS model of male discrimination perceptions

\begin{tabular}{|c|c|c|c|c|}
\hline & (1) & (2) & (3) & (4) \\
\hline Age & $\begin{array}{l}0.002 \\
(0.001)\end{array}$ & $\begin{array}{l}0.000 \\
(0.002)\end{array}$ & $\begin{array}{l}0.002 \\
(0.001)\end{array}$ & $\begin{array}{l}0.002 \\
(0.001)\end{array}$ \\
\hline Gender & $\begin{array}{l}-1.354 \\
(0.032)^{* *}\end{array}$ & $\begin{array}{l}-1.547 \\
(0.099)^{* *}\end{array}$ & $\begin{array}{l}-1.250 \\
(0.093)^{* *}\end{array}$ & $\begin{array}{l}-1.288 \\
(0.064)^{* *}\end{array}$ \\
\hline Income & $\begin{array}{l}-0.002 \\
(0.003)\end{array}$ & $\begin{array}{l}-0.002 \\
(0.003)\end{array}$ & $\begin{array}{l}-0.002 \\
(0.003)\end{array}$ & $\begin{array}{l}0.002 \\
(0.005)\end{array}$ \\
\hline GCSE & $\begin{array}{l}-0.041 \\
(0.058)\end{array}$ & $\begin{array}{l}-0.038 \\
(0.058)\end{array}$ & $\begin{array}{l}0.007 \\
(0.080)\end{array}$ & $\begin{array}{l}-0.041 \\
(0.058)\end{array}$ \\
\hline A-level & $\begin{array}{l}0.007 \\
(0.059)\end{array}$ & $\begin{array}{l}0.013 \\
(0.059)\end{array}$ & $\begin{array}{l}0.042 \\
(0.080)\end{array}$ & $\begin{array}{l}0.007 \\
(0.059)\end{array}$ \\
\hline Degree & $\begin{array}{l}-0.100 \\
(0.056)\end{array}$ & $\begin{array}{l}-0.095 \\
(0.056)\end{array}$ & $\begin{array}{l}-0.019 \\
(0.077)\end{array}$ & $\begin{array}{l}-0.101 \\
(0.056)\end{array}$ \\
\hline Not in paid work & $\begin{array}{l}-0.007 \\
(0.041)\end{array}$ & $\begin{array}{l}-0.009 \\
(0.041)\end{array}$ & $\begin{array}{l}-0.009 \\
(0.041)\end{array}$ & $\begin{array}{l}-0.006 \\
(0.041)\end{array}$ \\
\hline Other & $\begin{array}{l}-0.046 \\
(0.064)\end{array}$ & $\begin{array}{l}-0.046 \\
(0.064)\end{array}$ & $\begin{array}{l}-0.045 \\
(0.064)\end{array}$ & $\begin{array}{l}-0.046 \\
(0.064)\end{array}$ \\
\hline Spouse & $\begin{array}{l}0.134 \\
(0.036) * *\end{array}$ & $\begin{array}{l}0.139 \\
(0.037)^{* *}\end{array}$ & $\begin{array}{l}0.134 \\
(0.036)^{* *}\end{array}$ & $\begin{array}{l}0.135 \\
(0.036)^{* *}\end{array}$ \\
\hline Left-right & $\begin{array}{l}0.167 \\
(0.008)^{* *}\end{array}$ & $\begin{array}{l}0.166 \\
(0.008)^{* *}\end{array}$ & $\begin{array}{l}0.167 \\
(0.008)^{* *}\end{array}$ & $\begin{array}{l}0.167 \\
(0.008)^{* * *}\end{array}$ \\
\hline Libertarian-authoritarian & $\begin{array}{l}0.175 \\
(0.008)^{* *}\end{array}$ & $\begin{array}{l}0.175 \\
(0.008)^{* *}\end{array}$ & $\begin{array}{l}0.174 \\
(0.008)^{* *}\end{array}$ & $\begin{array}{l}0.175 \\
(0.008)^{* *}\end{array}$ \\
\hline Gender*age & & $\begin{array}{l}0.004 \\
(0.002)^{*}\end{array}$ & & \\
\hline Gender*GCSE & & & $\begin{array}{l}-0.096 \\
(0.115)\end{array}$ & \\
\hline Gender*A-level & & & $\begin{array}{l}-0.067 \\
(0.113)\end{array}$ & \\
\hline Gender*degree & & & $\begin{array}{l}-0.161 \\
(0.105)\end{array}$ & \\
\hline Gender*income & & & & $\begin{array}{l}-0.007 \\
(0.006)\end{array}$ \\
\hline Constant & $\begin{array}{l}3.011 \\
(0.098)^{* *}\end{array}$ & $\begin{array}{l}3.100 \\
(0.107)^{* *}\end{array}$ & $\begin{array}{l}2.960 \\
(0.106)^{* *}\end{array}$ & $\begin{array}{l}2.973 \\
(0.102)^{* * *}\end{array}$ \\
\hline$R^{2}$ & 0.14 & 0.14 & 0.14 & 0.14 \\
\hline$N$ & 17,260 & 17,260 & 17,260 & 17,260 \\
\hline
\end{tabular}

Coefficients are log odds. Standard errors are in parentheses

$* p<0.05 ; * * p<0.01$ 
education levels and income levels, as neither of the interactions are statistically significant. Income and employment status are also not statistically significant in the additive model, but those with a spouse are less likely to perceive discrimination against men. These results hold when we model the effect of income as a categorical variable, when we remove controls for left-right and liberal-authoritarian values (see Online Appendix), and when we use subjective social class instead of household income (see Online Appendix). It is not therefore the case that perceptions of discrimination-or potential gender-based grievances about rising gender equality-are confined to lower income men, lower social class males, or men with lower levels of education. ${ }^{7}$ They are simply more prevalent among men.

Age is not predictive of perceptions of discrimination in the additive model (model 1), which is inconsistent with prior research in the US (Kehn \& Ruthig, 2013), but the interaction with gender is statistically significant and positive, suggesting that women are more likely to perceive discrimination against men as they get older but that there is little or no age effect for men. This is contrary to what we expected in $\mathrm{H} 2$, but using a polynomial smoothing function we plotted the relationship between age and perceiving discrimination against men for both men and women (shown in figures $\mathrm{A} 2 \mathrm{a}$ and $\mathrm{A} 2 \mathrm{~b}$ in the Online Appendix). This shows that the age effect for men is non-linear, with men becoming more likely to perceive discrimination against men up to about age 60, but then becoming less likely again at older ages. A curvilinear term was also significant when added to the additive model in Table 1.

We also ran the same models reported in Table 3 for different discrimination perceptions (towards women, white British people, and black and Asian people) and found, in all instances, that men held higher perceptions of discrimination against men, in favour of women, against white British people and in favour of black and Asian people, but the gender difference did not vary as predicted in the literature by low levels of income, education level, or working class social status. ${ }^{8}$ These additional results - with and without controls for left-right and liberal-authoritarian values where informative-are presented in Figures A.1 (a-e) in the Online Appendix.

We further argued that discrimination should be felt most among older men employed in the workforce, which led us to H3: that male discrimination will be higher for older employed men. We test this hypothesis directly by adding a three-way interaction for gender, age and employment status [employed, not in paid work (including retired)], or other (including students) to our model of male

\footnotetext{
${ }^{7}$ We do not confine our analysis to white working class or white lower education males, since specific racial expectations are related to perceptions of discrimination against working class white people, not working class men. Men of different ethnic backgrounds could equally perceive discrimination against men.

${ }^{8}$ Higher income women were slightly less likely than higher income men to perceive discrimination against white British people but there were no significant differences at low income levels; degree holding women were more likely to perceive discrimination against women, and degree holding men were less likely than men with A' Levels or GCSE level qualifications to perceive discrimination against men. Degree holding men and women were more likely to perceive discrimination against black and Asian people. All results can be found in Fig. A2 (a-e).
} 

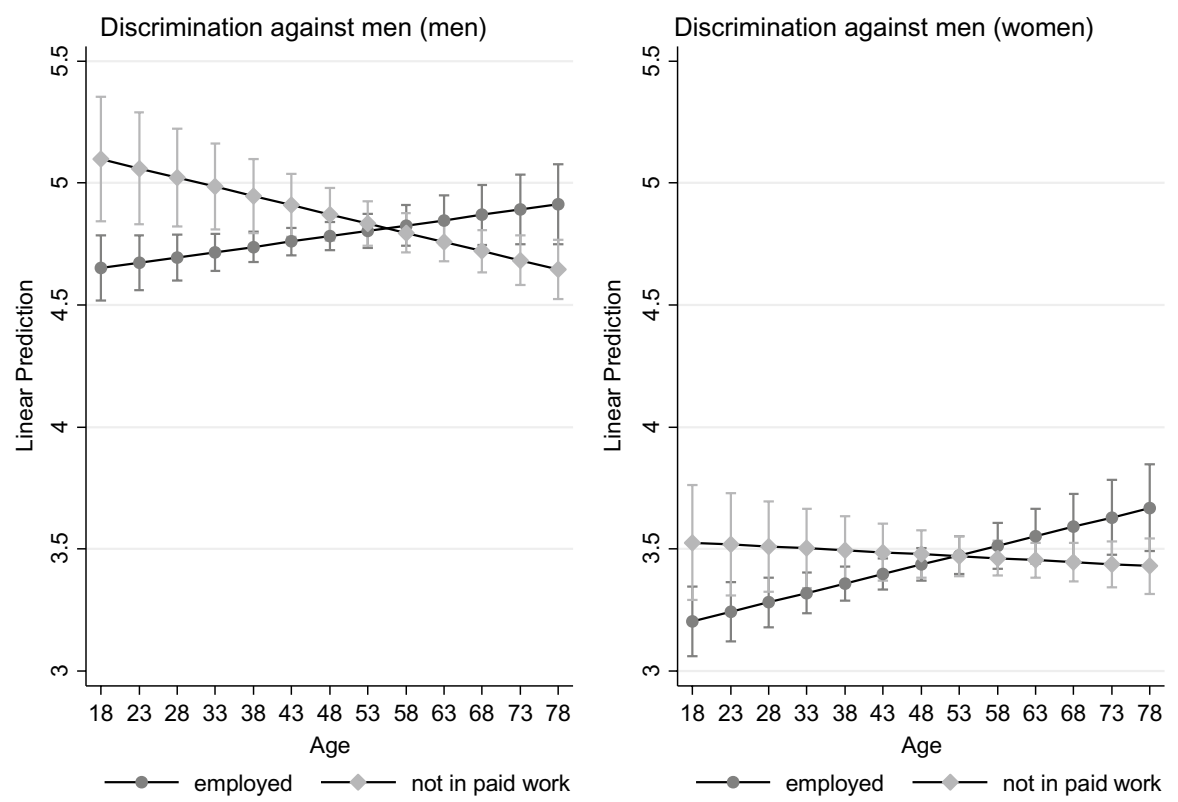

Fig. 3 Predicted discrimination values by age and work status, for men and women

discrimination perceptions. ${ }^{9}$ The predicted values for the relationship between age and discrimination perceptions for people in the workforce, separately for men and women, are shown in Fig. 3 (the full model can be found in Table A2 of the Online Appendix).

The results displayed in Fig. 3 do not provide support for $\mathrm{H} 3$. There is some evidence that older men in the workforce are more likely to perceive discrimination against men, as are older women in the workforce (indeed, the slope for age among working women is notably steeper than it is for out-of-work women). However, the distinction between in- and out-of-work males across the age distribution is important, as we find that it is younger out-of-work males who perceive the greatest discrimination against men. This also points to an economic-competition explanation for perceptions of discrimination against men, and a source of political grievance. While we cannot decisively tell whether it is competition with women in the workforce per se that leads to this relationship, we can deduce that the effect of age among men is complicated by work status. ${ }^{10}$

The explanation of men's perceptions of discrimination towards men is different to women's perceptions of discrimination towards men. Men do hold perceptions of

\footnotetext{
9 We cannot break down the type or sector of employment, and the sample is insufficiently distributed to examine type of non-employment, with the proportion unemployed $3 \%$, retired $29.5 \%$, student $4.5 \%$ and not working/other (undefined) $10.3 \%$.

${ }^{10}$ We note, however, that only the effect of employment/not working among older men is robust once we remove the left-right and libertarian-authoritarian value controls as a robustness check, and so we are tentative in our conclusions regarding younger out-of-work males.
} 
greater discrimination against men if they are older, but the effect of age is stronger for women, who are less likely overall to think there is discrimination against men. Furthermore, while the literature points to greater sources of potential gender-based competition and resentment among lower-income, less-educated and working-class males, we find that perceptions of discrimination are higher among men than women across the income distribution, across education levels, and also across social class identification, whilst these variables in themselves do not predict perceiving discrimination against men.

Each of these observations is consistent with a gender-based backlash against changes in the workforce which have increased (although not equalised) opportunities for women, and increased economic competition for men. The next stage of our empirical analysis examines whether there has been a political backlash in the form of a gender-based discrimination vote in support for Britain's exit from the European Union; an event argued to have been driven by the resentment and nostalgic preferences of many voters who wanted to reverse a broad array of economic, social, political and cultural changes that have taken place over time.

\section{The Effects of Male Discrimination Perceptions on Brexit Vote}

We predicted that there will be an effect on Leave support of perceiving discrimination against men $(\mathrm{H} 4)$, and that this effect will be greater among men, since a resentment basis to vote choice should be identified most strongly within the group that experiences the particular grievance (H5). We examine the relationship between male discrimination perceptions, for men and women, in a logistic regression model of EU referendum support. We report the effects for discrimination with (model 2) and without (model 1) controls for the other perceptions of discrimination, and with the lagged dependent variable (model 3). Models 2 and 3 present a conservative test of our hypotheses, since perceptions of discrimination against white British and men are correlated, particularly for men, and since both perceptions of discrimination and EU referendum preference are expected to be quite stable over the two panel waves. We further report, in Fig. 4, the results of a model interacting all of the discrimination measures with gender, in order to provide a benchmark for these relationships. The full results for these models are found in Table A3 in the Online Appendix.

The results in Table 4 reveal that discrimination perceptions are important for understanding people's motivation to support Leave in the EU referendum. Believing men are discriminated against increases the likelihood of voting Leave amongst both men and women. Furthermore, this effect is significantly greater for men compared to women; a finding that holds in each of the three models, including the other discrimination perceptions (model 2), and also including the lagged dependent variable (model 3). We suggest that these are conservative tests of discrimination perceptions. This is because we control for past EU referendum vote, but we also control for liberal-authoritarian values, which may be causally downstream of perceptions of discrimination for some individuals, and we control for education levels, which will likely shape gender-based discrimination perceptions. 

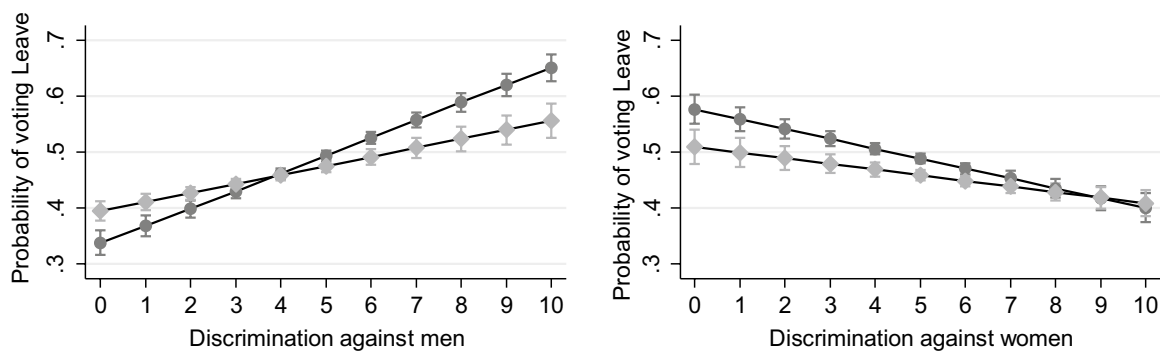

$\longrightarrow$ men w $\longrightarrow$ women
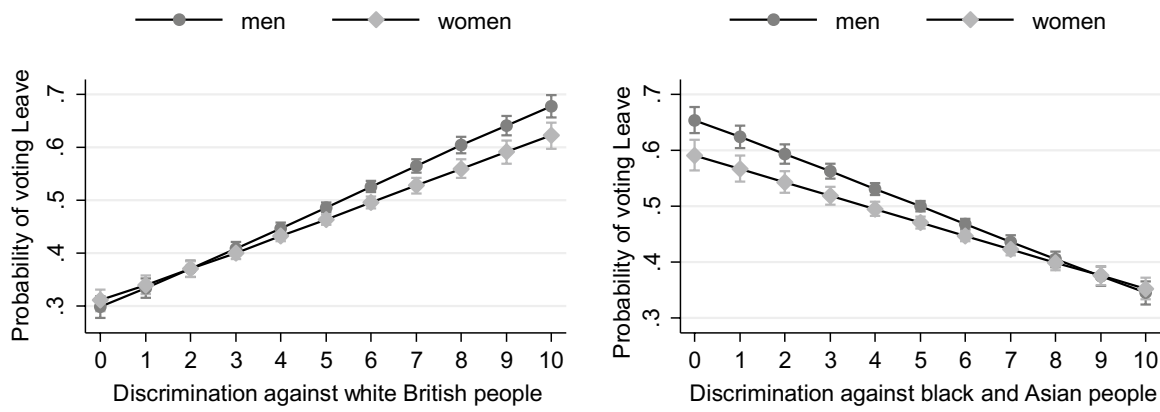

- men w women

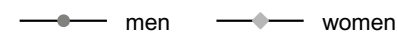

Fig. 4 Predicted Leave vote intention by discrimination perceptions, for men and women

Figure 4 shows that the effect of male discrimination perceptions is substantially stronger among men. The effects of the other discrimination perceptions are also larger amongst men than women, although the gender difference is greatest for perceptions of discrimination against men. The predicted values on Leave voting are of an equivalent size for perceptions of discrimination against men (among men) as they are for the measures of discrimination against white British people and black and Asian people; roughly doubling the likelihood of voting Leave across the scales.

In summary, gender-based discrimination (against men) is a significant predictor for Leave support in the Brexit referendum, consistent with a gender backlash explanation in the referendum, and men are more likely to support Leave on the basis of resentment or grievances towards women. These effects are of an equivalent size, among men, to the effects of perceptions of discrimination towards white British people and ethnic minorities. ${ }^{11}$

In a final set of analysis (not shown here), we explored whether the effects of perceiving discrimination were greater for low income or low education males (including an interaction effect for gender and income, and gender and education level), and older and younger men in employment, or not working. This serves to further test whether grievance voting is greater among lower income or low education men,

\footnotetext{
11 We note that a series of robustness checks point to the interaction between gender and male discrimination as the stronger of the two interactions, across model specifications. For example, when liberalauthoritarian values are removed from the model, male discrimination perceptions, and its interaction with gender, is unchanged in statistical effect, but the gender differences in the effect of perceiving discrimination in black and Asian people are overlapping.
} 
Table 4 Logistic regression model of discrimination against men predicting EU referendum vote with alternative model specifications

\begin{tabular}{|c|c|c|c|}
\hline & (1) & (2) & (3) \\
\hline Discrimination against men & $\begin{array}{l}0.195 \\
(0.014)^{* *}\end{array}$ & $\begin{array}{l}0.075 \\
(0.016)^{* *}\end{array}$ & $\begin{array}{l}0.133 \\
(0.033)^{* *}\end{array}$ \\
\hline Gender & $\begin{array}{l}0.369 \\
(0.094)^{* *}\end{array}$ & $\begin{array}{l}0.204 \\
(0.097)^{*}\end{array}$ & $\begin{array}{l}0.456 \\
(0.220)^{*}\end{array}$ \\
\hline Discrimination against men*gender & $\begin{array}{l}-0.097 \\
(0.020)^{* *}\end{array}$ & $\begin{array}{l}-0.052 \\
(0.021)^{*}\end{array}$ & $\begin{array}{l}-0.097 \\
(0.046)^{*}\end{array}$ \\
\hline Age & $\begin{array}{l}0.019 \\
(0.001)^{* *}\end{array}$ & $\begin{array}{l}0.017 \\
(0.001)^{* *}\end{array}$ & $\begin{array}{l}0.015 \\
(0.003)^{* *}\end{array}$ \\
\hline Income & $\begin{array}{l}-0.004 \\
(0.004)\end{array}$ & $\begin{array}{l}-0.007 \\
(0.004)\end{array}$ & $\begin{array}{l}0.007 \\
(0.009)\end{array}$ \\
\hline GCSE & $\begin{array}{l}-0.269 \\
(0.074)^{* *}\end{array}$ & $\begin{array}{l}-0.289 \\
(0.075)^{* *}\end{array}$ & $\begin{array}{l}-0.125 \\
(0.162)\end{array}$ \\
\hline A-level & $\begin{array}{l}-0.324 \\
(0.075)^{* *}\end{array}$ & $\begin{array}{l}-0.337 \\
(0.076)^{* *}\end{array}$ & $\begin{array}{l}0.126 \\
(0.169)\end{array}$ \\
\hline Degree & $\begin{array}{l}-0.656 \\
(0.070)^{* *}\end{array}$ & $\begin{array}{l}-0.653 \\
(0.071)^{* *}\end{array}$ & $\begin{array}{l}-0.097 \\
(0.159)\end{array}$ \\
\hline Authoritarian-libertarian values & $\begin{array}{l}0.224 \\
(0.012)^{* *}\end{array}$ & $\begin{array}{l}0.196 \\
(0.012)^{* *}\end{array}$ & $\begin{array}{l}0.046 \\
(0.028)\end{array}$ \\
\hline Immigration attitudes & $\begin{array}{l}-0.552 \\
(0.014)^{* *}\end{array}$ & $\begin{array}{l}-0.496 \\
(0.014)^{* *}\end{array}$ & $\begin{array}{l}-0.333 \\
(0.031)^{* *}\end{array}$ \\
\hline British Identity & $\begin{array}{l}0.128 \\
(0.014)^{* *}\end{array}$ & $\begin{array}{l}0.128 \\
(0.014)^{* *}\end{array}$ & $\begin{array}{l}0.134 \\
(0.032)^{* *}\end{array}$ \\
\hline Discrimination against women & & $\begin{array}{l}-0.045 \\
(0.013)^{* *}\end{array}$ & \\
\hline Discrimination against white British & & $\begin{array}{l}0.160 \\
(0.011)^{* *}\end{array}$ & \\
\hline Discrimination against Black and Asian & & $\begin{array}{l}-0.092 \\
(0.011)^{* *}\end{array}$ & \\
\hline EU referendum vote in Wave 9 (June-July 2016) & & & $\begin{array}{l}5.274 \\
(0.100)^{* *}\end{array}$ \\
\hline Constant & $\begin{array}{l}-1.316 \\
(0.168)^{* *}\end{array}$ & $\begin{array}{l}-0.710 \\
(0.190)^{* *}\end{array}$ & $\begin{array}{l}-3.877 \\
(0.412)^{* *}\end{array}$ \\
\hline$N$ & 17,455 & 17,455 & 11,295 \\
\hline
\end{tabular}

Coefficients are log odds. Standard errors are in parentheses

$* p<0.05 ; * * p<0.01$

even if discrimination perceptions were not predicted by these combinations. In no instances did we find evidence of a conditioning effect of low income or low education among men, but we did find a stronger effect of discrimination-based EU referendum support for younger males out of work, consistent with their stronger perceptions (see Fig. 3 and A3 in the Online Appendix). People acquire perceptions of 
discrimination as a function of the combination of their gender, age, and working status (as shown in Sect. 4), but the relationship of those attitudes to Brexit preference is not significantly stronger as a function of being in work (among older males), or having a lower income or education level, but it is among younger out of work males. Our findings show that perceiving discrimination against men has a substantial and significant effect on Brexit vote intention, most notably among men, and is consistent with a gender-based backlash explanation resulting from the experiences and perceptions of younger men, particularly those not in the workforce, as well as being greater and more significant among men overall.

\section{Robustness and Extension of Results}

The BES internet panel affords a range of possible extensions and checks on our results, some of which have been discussed already. In addition, we examined the longevity of effects on subsequent Brexit preference in later BES panel waves, and found the effects to be robust. We modelled the effects of discrimination on Brexit preferences instead of vote intention, since vote intention after the EU referendum may be influenced by expectations and attitudes about another referendum. Using an alternative dependent variable (attitudes towards independence or integration, where $0=$ unite fully with the European Union, and $10=$ protect our independence from the EU) produced very similar support for our argument and our hypotheses. The results can be found in Fig. A4 of the Online Appendix.

We also modelled the effects of a different attitudinal measure concerning gender equality. This question, which represents a long-standing item in BES in-person post-election surveys, ${ }^{12}$ does not provide us with the ability to examine whether attitudes about men and women are symmetrical (zero-sum) or directional (for or against each group), but it does enable us to explore whether it also produces an additional explanation of Brexit support. This was indeed the case. Agreeing that 'equal opportunities for women have gone too far' is a strong and significant predictor of EU referendum vote intention, in addition to the same controls used in our models in Sect. 5. However, we find no significant differences by gender, or by age, in how this variable is related to EU referendum vote. The problem with the 'gone too far' measure is that we do not know what is meant by the mean score: 'about right', which could mean that gender equality, or gender inequality, is about right, thereby not providing meaningful interpretation.

Finally, we explored the impact of confining our results to only white British respondents in the BES. While we have insufficient numbers of ethnic minority respondents to condition each set of results on ethnicity, as might be implied in the literature pointing particularly to white working class male resentments and

\footnotetext{
12 "Please say whether you think these things have gone too far or have not gone far enough in Britain: attempts to give equal opportunities to women". The item has not been asked sufficiently continuously to provide a useful time series.
} 
grievances, restricting our results to only white British respondents ( $91 \%$ of the sample), led to (unsurprisingly) equivalent results.

\section{Conclusions}

It is not entirely clear why researchers have largely ignored the possible effect of gender and gender equality related economic and social change on Brexit vote choice. One reason could be the absence of aggregate-level differences between men and women in the overall vote. Another might be the absence of explicit gender-based campaigning in the EU referendum campaign itself. These two realities ignore the importance of grievance-based accounts of votes for populism and populist causes which relate in particular to white, working class men. By referring back to the literature on this topic, we generated a series of hypotheses about the possible impact of a broader gender-based backlash in the Brexit referendum than has been identified to date.

Using novel measures in the British Election Study Internet Panel measuring perceptions of discrimination against and in favour of men and women, we found that one in five respondents perceived discrimination against men. This was highest amongst men of all ages, although it was particularly substantial for younger men who are not employed. Interestingly, income and education were not predictors of perceiving discrimination against men, indicating that the gender-based backlash is not just a product of socioeconomic disadvantage as commonly conceived. This suggests that the cultural backlash cannot be completely tied to economic marginalisation without consideration of gender, working status and age. With this in mind, studying the sources of men's resentment on the grounds of gender is an important future research agenda, especially as rising gender equality may well polarize attitudes further along the lines of gender, age, and employment status.

We also found that perceiving discrimination against men is a significant predictor of voting Leave at the EU referendum, especially for men, even when controlling for socioeconomic status, other attitudes related to the referendum vote, other discrimination perceptions, and prior EU support. These findings show that, whilst there was no gap between men and women in support for Leave/Remain at the referendum, gender nevertheless played a role in the outcome. This is important because it shows that even in contexts where gender is not particularly primed or salient, gender-based resentment is still important for political behaviour. The findings from the US show that perceptions of gender favouritism and hostile sexism mattered for voters' choice of Trump in the 2016 presidential election. We show that these have the potential to be generalised to other contexts where they also have explanatory power. Future research into populist outcomes especially, as well as elections more generally, should pay more attention to gender-based resentment. Moreover, these findings show that large-scale social changes, such as rising gender equality, may have consequences for political behaviour that we should study further. This includes also examining the effects of holding progressive or egalitarian gender attitudes, as well as the gender backlash. 
In terms of Brexit, the significant relationship between gender-based resentment and vote choice lends support to the argument that the vote to leave the EU represented a rejection of social, economic, and cultural change. It was not just a vote about policy direction, but about the direction of society as a whole. This perhaps indicates that men who hold gender-based resentments may be a group that becomes particularly frustrated if a post-Brexit Britain does not live up to their expectations. More broadly, the results also suggest that there is a significant minority of men who may vote in British elections on the basis of anger and resentment about the unfair treatment of men in society. More attention should be given to the implications of this for future political outcomes, as well as how to increase support for gender equality across the whole population.

Supplementary Information The online version contains supplementary material available at https://oi. org/10.1007/s11109-021-09704-y.

Acknowledgements We are grateful to the Editor and reviewers of Political Behavior for their insightful comments, and also to participants of the Elections, Public Opinion and Parties conference (2018) and the Nuffield College Political Science Seminar. We gratefully acknowledge funding of the British Election Study and this research provided by the Economic and Social Research Council grant number Award ES/K005294/1. Replication materials are available at: https://doi.org/10.7910/DVN/YHNCZQ.

Open Access This article is licensed under a Creative Commons Attribution 4.0 International License, which permits use, sharing, adaptation, distribution and reproduction in any medium or format, as long as you give appropriate credit to the original author(s) and the source, provide a link to the Creative Commons licence, and indicate if changes were made. The images or other third party material in this article are included in the article's Creative Commons licence, unless indicated otherwise in a credit line to the material. If material is not included in the article's Creative Commons licence and your intended use is not permitted by statutory regulation or exceeds the permitted use, you will need to obtain permission directly from the copyright holder. To view a copy of this licence, visit http://creativecommons.org/licen ses/by/4.0/.

\section{References}

Becker, S. O., Fetzer, T., \& Novy, D. (2017). Who voted for Brexit? A comprehensive district-level analysis. Economic Policy, 32(92), 601-651. https://doi.org/10.1093/epolic/eix012.

Berridge, D., Penn, R., \& Ganjali, M. (2009). Changing attitudes to gender roles. International Sociology, 24(3), 346-367. https://doi.org/10.1177/0268580909102912.

Bock, J., Byrd-Craven, J., \& Burkley, M. (2017). The role of sexism in voting in the 2016 presidential election. Personality and Individual Differences, 119, 189-193. https://doi.org/10.1016/j.paid.2017. 07.026.

Bonikowski, B. (2017). Ethno-nationalist populism and the mobilization of collective resentment. British Journal of Sociology, 68, S181-S213. https://doi.org/10.1111/1468-4446.12325.

Bromley-Davenport, H., MacLeavy, J., \& Manley, D. (2018). Brexit in Sunderland: The production of difference and division in the UK referendum on European Union membership. Environment and Planning C: Politics and Space. https://doi.org/10.1177/0263774X18804225.

Cassino, D. (2016). Why more American men feel discriminated against. . Harvard Business Review.

Clarke, H. D., Goodwin, M., \& Whiteley, P. (2017). Why Britain voted Forbrexit: An individual-level analysis of the 2016 referendum vote. Parliamentary Affairs, 70(3), 439-464. https://doi.org/10. $1093 / \mathrm{pa} / \mathrm{gsx} 005$.

Colantone, I., \& Stanig, P. (2018). Global competition and brexit. American Political Science Review, 112(02), 201-218. https://doi.org/10.1017/S0003055417000685. 
Daddow, O., \& Hertner, I. (2019). Interpreting toxic masculinity in political parties: A framework for analysis. Party Politics. https://doi.org/10.1177/1354068819887591.

Eagly, A. H., \& Karau, S. J. (2002). Role congruity theory of prejudice toward female leaders. Psychological Review, 109(3), 573-598. https://doi.org/10.1037/0033-295X.109.3.573.

Fetzer, T. (2019). Did austerity cause brexit? American Economic Review, 109(11), 3849-3886. https:// doi.org/10.1257/aer.20181164.

Fieldhouse, E., Green, J., Evans, G., Schmitt, H., van Eijk, C., Mellon, J., \& Prosser, C. (2015). British Election Study internet panel wave. https://doi.org/10.15127/1.293723.

Fitzenberger, B., \& Wunderlich, G. (2004). The changing life cycle pattern in female employment: A comparison of Germany and the UK. Scottish Journal of Political Economy, 51(3), 302-328. https:// doi.org/10.1111/j.0036-9292.2004.00308.x.

Garcia-Retamero, R., \& López-Zafra, E. (2006). Prejudice against women in male-congenial environments: Perceptions of gender role congruity in leadership. Sex Roles, 55(1-2), 51-61. https://doi. org/10.1007/s11199-006-9068-1.

Gest, J. (2016). The new minority. . Oxford University Press.

Gest, J., Reny, T., \& Mayer, J. (2018). Roots of the radical right: Nostalgic deprivation in the United States and Britain. Comparative Political Studies, 51(13), 1694-1719. https://doi.org/10.1177/ 0010414017720705.

Green, J., Timothy, H., \& Edward, F. (2021). Who gets what: The economy, relative gains, and brexit. British Journal of Political Science. https://doi.org/10.1017/S0007123420000551.

Gidron, N., \& Hall, P. A. (2017). The politics of social status: Economic and cultural roots of the populist right. British Journal of Sociology, 68, S57-S84. https://doi.org/10.1111/1468-4446.12319.

Givens, T. E. (2004). The radical right gender gap. Comparative Political Studies, 37(1), 30-54. https:// doi.org/10.1177/0010414003260124.

Glick, P., \& Fiske, S. T. (1996). The Ambivalent Sexism Inventory: Differentiating hostile and benevolent sexism. Journal of Personality and Social Psychology, 70(3), 491-512. https://doi.org/10.1037/ 0022-3514.70.3.491.

Glick, P., \& Fiske, S. T. (2011). Ambivalent sexism revisited. Psychology of Women Quarterly, 35(3), 530-535. https://doi.org/10.1177/0361684311414832.

Goldman, S. K. (2018). Fear of gender favoritism and vote choice during the 2008 presidential primaries. The Journal of Politics, 80(3), 786-799. https://doi.org/10.1086/697123.

Goodwin, M., \& Heath, O. (2016). The 2016 referendum, brexit and the left behind: An aggregate-level analysis of the result. Political Quarterly, 87(3), 323-332. https://doi.org/10.1111/1467-923X. 12285.

Goodwin, M., \& Milazzo, C. (2017). Taking back control? Investigating the role of immigration in the 2016 vote for Brexit. The British Journal of Politics and International Relations, 19(3), 450-464. https://doi.org/10.1177/1369148117710799.

Grasso, M. T., Farrall, S., Gray, E., Hay, C., \& Jennings, W. (2019). Thatcher's children, blair's babies, political socialization and trickle-down value change: An age, period and cohort analysis. British Journal of Political Science, 49(1), 17-36. https://doi.org/10.1017/S0007123416000375.

Guerrina, R., \& Murphy, H. (2016). Strategic silences in the brexit debate: Gender, marginality and governance. Journal of Contemporary European Research, 12(4), 872-880.

Hobolt, S. B. (2016). The Brexit vote: A divided nation, a divided continent. Journal of European Public Policy, 23(9), 1259-1277. https://doi.org/10.1080/13501763.2016.1225785.

Iakhnis, E., Rathbun, B., Reifler, J., \& Scotto, T. J. (2018). Populist referendum: Was 'brexit' an expression of nativist and anti-elitist sentiment? Research and Politics, 5(2), 2053168018773964. https:// doi.org/10.1177/2053168018773964.

Immerzeel, T., Coffé, H., \& van der Lippe, T. (2015). Explaining the gender gap in radical right voting: A cross-national investigation in 12 Western European countries. Comparative European Politics, 13(2), 263-286. https://doi.org/10.1057/cep.2013.20.

Jennings, W., \& Stoker, G. (2016). The bifurcation of politics: Two Englands. The Political Quarterly, 87(3), 372-382. https://doi.org/10.1111/1467-923X.12228.

Jennings, W., \& Stoker, G. (2017). Tilting towards the cosmopolitan axis? Political change in England and the 2017 general election. Political Quarterly, 88(3), 359-369. https://doi.org/10.1111/1467$923 X .12403$.

Kay, T. (1996). Women's work and women's worth: The leisure implications of women's changing employment patterns. Leisure Studies, 15(1), 49-64. https://doi.org/10.1080/02614369600390251. 
Kehn, A., \& Ruthig, J. C. (2013). Perceptions of gender discrimination across six decades: The moderating roles of gender and age. Sex Roles, 69(5-6), 289-296. https://doi.org/10.1007/ s11199-013-0303-2.

Norris, P., \& Inglehart, R. F. (2019). Cultural backlash: Trump, brexit, and authoritarian populism. . Cambridge University Press.

Norton, M. I., \& Sommers, S. R. (2011). Whites see racism as a zero-sum game that they are now losing. Perspectives on Psychological Science, 6(3), 215-218. https://doi.org/10.1177/1745691611406922.

Phelan, J. E., \& Rudman, L. A. (2010). Prejudice toward female leaders: Backlash effects and women's impression management dilemma. Social and Personality Psychology Compass, 4(10), 807-820. https://doi.org/10.1111/j.1751-9004.2010.00306.x.

Pratto, F., Sidanius, J., Stallworth, L. M., \& Malle, B. F. (1994). Social dominance orientation: A personality variable predicting social and political attitueds. Journal of Personality and Social Psychology, 67(4), 741-763.

Richards, L., Heath, A., \& Elgenius, G. (2020). Remainers are nostalgic too: An exploration of attitudes towards the past and Brexit preferences. British Journal of Sociology, 71(1), 74-80. https://doi.org/ 10.1111/1468-4446.12710.

Roantree, B., \& Vira, K. (2018). The rise and rise of women's employment in the UK IFS Briefing Note BN234.

Roos, P. A., \& Stevens, L. M. (2018). Integrating occupations: Changing occupational sex segregation in the United States from 2000 to 2014. Demographic Research, 38(1), 127-154. https://doi.org/10. 4054/DemRes.2018.38.5.

Scott, J. (2008). Changing gender role attitudes. In J. Scott, S. Dex, \& H. Joshi (Eds.), Women and Employment: Changing Lives and New Challenges. (pp. 156-176). Edward Elgar.

Spierings, N., \& Zaslove, A. (2015). Gendering the vote for populist radical-right parties. Patterns of Prejudice, 49(1-2), 135-162. https://doi.org/10.1080/0031322X.2015.1024404.

Steenbergen, M. R., \& Siczek, T. (2017). Better the devil you know? Risk-taking, globalization and populism in Great Britain. European Union Politics, 18(1), 119-136. https://doi.org/10.1177/14651 16516681858.

Steenvoorden, E., \& Harteveld, E. (2018). The appeal of nostalgia: The influence of societal pessimism on support for populist radical right parties. West European Politics, 41(1), 28-52. https://doi.org/ 10.1080/01402382.2017.1334138.

Surridge, P. (2016). Education and liberalism: Pursuing the link. Oxford Review of Education, 42(2), 146-164. https://doi.org/10.1080/03054985.2016.1151408.

Swales, K. (2016). Understanding the Leave vote. NatCen Social Research 1-29.

Tilley, J. R. (2005). Research note: Libertarian-authoritarian value change in Britain, 1974-2001. Political Studies, 53(2), 442-453. https://doi.org/10.1111/j.1467-9248.2005.00537.x.

Publisher's Note Springer Nature remains neutral with regard to jurisdictional claims in published maps and institutional affiliations. 